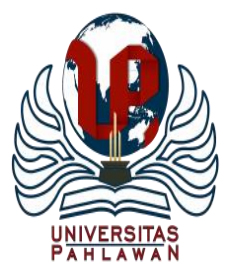

Edukatif : Jurnal Ilmu Pendidikan Volume 3 Nomor 4 Tahun 2021 Halm 1470 - 1479

EDUKATIF: JURNAL ILMU PENDIDIKAN

Research \& Learning in Education

https://edukatif.org/index.php/edukatif/index

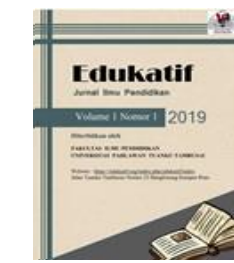

\title{
Pengaruh Self Regulated Learning dan Self Efficacy Terhadap Hasil Belajar Ekonomi Peserta Didik dalam Pembelajaran Daring di Era Covid-19
}

\author{
Muti'atuz Zahro $^{1 \otimes}$, Jun Surjanti ${ }^{2}$ \\ Universitas Negeri Surabaya, Indonesia ${ }^{1,2}$ \\ E-mail : mutiatuz.17080554052@ mhs.unesa.ac.id ${ }^{1}$ Junsurjanti@ gmail.com $^{2}$
}

\begin{abstract}
Abstrak
Dalam aktivitas belajar daring di era Covid-19 hasil belajar ekonomi peserta didik jurusan IPS MA Sunan Ampel masih belum tercapai optimal begitupun dengan tingkat self regulated learning dan tingkat self efficacy peserta didik yang juga belum tercapai secara optimal. Tujuan dari dilaksanakannya penelitian ini adalah untuk menganalisa terkait pengaruh self regulated learning dan self efficacy terhadap hasil belajar ekonomi peserta didik jurusan IPS MA Sunan ampel dalam pembelajaran secara daring di era Covid-19. Jenis pendekatan dalam penelitian ini dengan menggunakan kuantitatif sedangkan jenis penelitiannya adalah asosiatif kausal. Responden yang digunakan dalam penelitian ini sebanyak 92 peserta didik. Tahap pengumpulan data dalam penelitian ini dilakukan melalui kuesioner dan untuk tahap analisis data berbantu program SPSS. Hasil penelitian melaporkan bahwa 1) self regulated learning berkorelasi positif signifikan dengan hasil belajar ekonomi peserta didik dalam aktivitas belajar daring di era Covid-19,2) self efficacy berkorelasi positif signifikan terhadap hasil belajar ekonomi peserta didik dalam aktivitas belajar daring di era Covid-19, 3) self regulated learning dan self efficacy secara bersama-sama berpengaruh kuat terhadap hasil belajar ekonomi peserta didik dalam aktivitas belajar daring di era Covid-19.
\end{abstract}

Kata Kunci: Self Regulated Learning, Self Efficacy, Hasil Belajar.

\begin{abstract}
During online learning in Covid-19 pandemic, the economic learning outcomes of social science student in MA Sunan Ampel have not been achieved optimally as well as self regulated learning and self efficacy of student which have not been achieved optimally. The purpose of carrying out this study was to analyze the effect of self regulated learning and self efficacy on economic learning outcomes of social science student in MA Sunan Ampel in online learning during Covid-19. The type of approach in this study uses quantitative method and the type of study is associative causal. The respondents used were 92 students. Data were obtained through a questionnaire and data analysis assisted bySPSS program. The result of this study reported that 1) self regulated learning has a significant positive correlation with student's economic learning outecomes in online learning during Covid-19 pandemic, 2) self efficacy has a significant positive correlation with student's economic learning outecomes in online learning during Covid-19 pandemic, 3) self regulated learning and self efficacy together have a strong effect on student's economic learning outecomes in online learning during Covid-19 pandemic.
\end{abstract}

Keywords: Self Regulated Learning, Self Efficacy, Learning Outcomes.

Copyright (c) 20212021 Muti'atuz Zahro, Jun Surjanti

$\triangle$ Corresponding author

Email : mutiatuz.17080554052@mhs.unesa.ac.id

DOI : https://doi.org/10.31004/edukatif.v3i4.560

ISSN 2656-8063 (Media Cetak)

ISSN 2656-8071 (Media Online)

Edukatif : Jurnal Ilmu Pendidikan Vol 3 No 4 Tahun 2021 p-ISSN 2656-8063 e-ISSN 2656-8071 
1471 Pengaruh Self Regulated Learning dan Self Efficacy Terhadap Hasil Belajar Ekonomi Peserta Didik dalam Pembelajaran Daring di Era Covid-19 - A Muti'atuz Zahro, Jun Surjanti

DOI: https://doi.org/10.31004/edukatif.v3i4.560

\section{PENDAHULUAN}

Pendidikan adalah suatu inisiatif yang dikerjakan individu guna mendapat perubahan tingkah laku dirinya. Rangkaian kependidikan menekankan belajar sebagai aktivitas paling penting. Namun di era pandemi Covid-19 aktivitas belajar berbeda dari yang sebelumnya, yakni dilakukan secara daring. Hal ini turut mempengaruhi hasil belajar yang diperoleh peserta didik. Dilansir dari berita Liputan 6 pada tanggal 18 Agustus 2020, diperoleh informasi bahwa Saiful Munjani Research and Consulting (SMRC) merilis data hasil survei terkait aktivitas belajar online di era penyebaran Covid-19 yang menunjukkan bahwa banyak peserta didik memiliki permasalahan dalam belajar (Liputan 6, 2020). Terdapat penurunan kelulusan ujian nasional peserta didik dalam pembelajaran di era Covid-19 (Sintema, 2020). Selama Covid-19 peserta didik beralih ke sistem online secara mendadak yang mengakibatkan hasil belajar tidak maksimal (Patricia, 2020). Pembelajaran daring di era Covid-19 memicu beberapa permasalahan peserta didik seperti permasalahan dalam mengatur belajarnya juga kekhawatiran dalam mengikuti kegiatan pembelajaran yang mana akan mempengaruhi capaian belajar (Abisha Meji \& Dennison, 2020). Pembelajaran daring turut menimbulkan kebingungan pembelajar sehingga dapat menurunkan hasil belajar (Argaheni, 2020).

Pada kenyataan di lapangan, permasalahan hasil belajar daring di era Covid-19 juga terjadi di kelas X, XI, dan XII IPS MA Sunan Ampel pada semester gasal tahun ajaran 2020/2021. Berdasarkan keterangan data yang diberikan guru ekonomi di MA Sunan Ampel, diperoleh informasi bahwa sebanyak $75 \%$ pebelajar di kelas X IPS, 65\% pebelajar di kelas XI IPS, dan 73\% pebelajar di kelas XII IPS memiliki nilai kurang daripada batas KKM (Kriteria Ketuntasan Minimal). Hasil belajar yang diperoleh seorang individu pebelajar dapat dipengaruhi oleh faktor internal berupa self regulated learning dan self efficacy. Self regulated learning maupun self efficacy sangat berperan penting terhadap pencapaian belajar yang didapatkan oleh peserta didik yang dibuktikan dengan korelasi positif antara variabel self regulated learning, self efficacy, dan capaian belajar (Agustiani et al., 2016).

Self regulated learning merupakan faktor pemegang peranan penting dalam rangkaian aktivitas pembelajaran. Berdasarkan penelitian terdahulu diungkapkan bahwasanya self regulated learning secara positif berhubungan terhadap hasil akademik individu pebelajar (Agustiani et al., 2016). Penelitian lain menunjukkan bahwa peserta didik di sekolah berprestasi tinggi turut memiliki self regulated learning dengan tingkatan yang juga lebih tinggi (Guo et al., 2019). Penelitian yang dilakukan oleh Xiao \& Yao, dkk (2019) turut membuktikan bahwa pelajar dengan self regulated learning optimal secara akademis cenderung dapat mencapai keberhasilan dibandingkan pelajar dengan self regulated learning kurang optimal. Self regulated learning memiliki keterkaitan positif signifikan dengan pencapaian akademis, dikarenakan ketika diri seorang individu pebelajar tertanam self regulated learning yang baik maka akan mampu mengatur dan mengembangkan cara yang digunakan dalam aktivitas belajar sehingga menjadi arahan dalam mencapai hasil akademis (Alotaibi et al., 2017). Kelompok peseta didik dengan self regulated learning rendah memperoleh hasil capaian belajar yang juga lebih rendah, berbanding terbalik dengan kelompok kelompok individu pebelajar self regulated learning tinggi yang mana turut menunjukkan hasil belajar yang lebih tinggi (Dörrenbächer \& Perels, 2016). Self regulated learning secara signifikan mempunyai korelasi terhadap hasil akademik seorang pelajar (Shing \& Rameli, 2020). Penelitian lain juga mengungkapkan hasil serupa yakni secara signifikan ada pengaruh antara tingkatan self regulated learning terhadap capaian hasil akademis pebelajar (Yahaya et al., 2020). Namun hasil berbeda ditunjukkan penelitian Saraswati (2017) yang menunjukkan self regulated learning tidak berhubungan dengan hasil akademik.

Dalam pembelajaran daring peserta didik membutuhkan Self regulated learning yang tinggi guna mengelola aktivitas belajarnya. Namun hal tersebut belum tercapai optimal, tingkat tanggung jawab peserta didik dalam mengelola belajarnya masih rendah. Hal itut tercermin dari rutinitas belajar yang dilakukan peserta didik di luar pembelajaran wajib ekonomi secara daring, diketahui sebanyak $32 \%$ peserta didik jurusan 
1472 Pengaruh Self Regulated Learning dan Self Efficacy Terhadap Hasil Belajar Ekonomi Peserta Didik dalam Pembelajaran Daring di Era Covid-19 - A Muti'atuz Zahro, Jun Surjanti

DOI: https://doi.org/10.31004/edukatif.v3i4.560

IPS MA Sunan Ampel belajar secara rutin, sedangkan 68\% lainnya belajar hanya ketika menjelang ujian. Fakta lain di lapangan juga menunjukkan kesadaran peserta didik dalam belajar masih belum optimal. Berdasarkan inisiatif belajar, diketahui $30 \%$ peserta didik jurusan IPS MA Sunan Ampel belajar atas kesadarannya sendiri dan $70 \%$ lainnya belajar hanya ketika diingatkan.

Faktor lainnya yang turut melingkupi seorang peserta didik ketika mengikuti rangkaian aktivitas belajar adalah self efficacy. Berdasarkan penelitian terdahulu dikemukakan bahwasanya self efficacy dapat sangat mempengaruhi ekologi belajar untuk mengembangkan perilaku keberlanjutan, keberlanjutan perilaku dapat ditingkatkan dengan meningkatkan efikasi diri karena efeknya dalam memediasi keberhasilan pembelajaran ekologi partisipatif (Surjanti et al., 2020). Penelitian lain turut mengungkapkan hasil bahwa pebelajar dengan tingkat self efficacy tinggi mampu meraih skor yang tinggi dalam aktivitas belajar sedangkan pebelajar dengan tingkat efikasi diri yang rendah maka turut meraih skor yang lebih rendah (Martin et al., 2019). Penelitian Ayllon \& Angel, dk (2019) juga melaporkan terdapat keterkaitan positif signifikan antara self efficacy dengan hasil belajar. Hal serupa turut dibuktikan dalam penelitian lain yang melaporkan bahwa terdapat korelasi signifikan antara self efficacy dengan skor akademik pebelajar (Tiyuri et al., 2018). Meningkatnya efikasi diri pada gilirannya turut mempengaruhi kinerja ujian menjadi lebih baik, dikarenakan pebelajar dengan level self efficacy yang baik mampu menetapkan tujuan yang lebih tinggi dan lebih realistis, merencanakan dan memantau dengan lebih baik, dan melaporkan kecemasan lebih rendah, yang pada gilirannya mendorong keberhasilan prestasi akademis (Roick \& Ringeisen, 2017). Seorang individu pebelajar dengan self efficacy tingkatan lebih tinggi cenderung meraih hasil belajar lebih tinggi (Honicke \& Broadbent, 2016). Penelitian lain juga melaporkan hasil serupa yakni self efficacy berpengaruh secara signifikan terhadap nilai perkuliahan dan pembelajaran praktis (Lee \& Mao, 2016). Tetapi hasil berbeda ditunjukkan penelitian Achufusi \& Utakaj, dkk (2019) yaitu self-efficacy tidak signifikan terhadap capaian peserta belajar didik.

Permasalahan lain di kelas IPS MA Sunan Ampel adalah self efficacy peserta didik masih belum optimal tercermin dari sering terlambat dan enggan mengerjakan tugas yang diberikan, juga mudah menyerah ketika mendapat materi agak sukar. Dari data ketepatan waktu pengumpulan tugas diketaui bahwa kelas $\mathrm{X}$ IPS sebanyak $46 \%$ peserta didik mengumpulkan tepat waktu, $46 \%$ peserta didik mengumpulkan terlambat, dan $8 \%$ peserta didik tidak mengumpulkan tugas. Untuk kelas XI IPS sebanyak $51 \%$ peserta didik mengumpulkan tepat waktu, $38 \%$ peserta didik mengumpulkan terlambat, dan $11 \%$ peserta didik tidak mengerjakan. Sedangkan untuk kelas XII IPS diketahui sebanyak 50\% peserta didik mengumpulkan tepat waktu, $43 \%$ peserta didik mengumpulkan tugas terlambat, dan sebanyak $7 \%$ peserta didik tidak mengerjakan tugas.

Berdasarkan pemaparan di atas, penulis tertarik menjadikan permasalahan tersebut sebagai penelitian dengan judul "Pengaruh Self Regulated Learning dan Self Efficacy Terhadap Hasil Belajar Ekonomi Peserta Didik dalam Pembelajaran Daring di Era Covid-19. Penelitian ini yang membedakan dengan penelitianpenelitian pada waktu sebelumnya ialah apabila penelitian di waktu sebelumnya menganalisis bagaimana keterkaitan self regulated learning dan self efficacy terhadap hasil belajar selama aktivitas pembelajaran tatap muka, maka dalam penelitian ini akan dibahas bagaimana keterkaitan self regulated learning dan self efficacy terhadap hasil belajar di era pandemi yang dilaksanakan dalam bentuk daring. Adapun tujuan dilaksanakannya penelitian ini guna: 1) menganalisis terkait pengaruh self regulated learning terhadap hasil belajar ekonomi peserta didik dalam aktivitas belajar daring di era Covid-19;2) menganalisis terkait pengaruh pengaruh self efficacy terhadap hasil belajar ekonomi peserta didik dalam aktivitas belajar daring di era Covid-19; 3) menganalisis terkait pengaruh self regulated learning dan self efficacy secara bersama-sama terhadap hasil belajar ekonomi peserta didik dalam aktivitas belajar daring di era Covid-19. Dengan dilakukannya penelitian ini, maka diharapkan dapat menjadi sumber informasi bagi pihak sekolah terkait peranan penting self regulated learning dan self efficacy terhadap hasil belajar sehingga dapat membantu upaya peningkatan hasil belajar dalam aktivitas pembelajaran yang dilaksanakan secara daring terutama di era Covid-19. 
1473 Pengaruh Self Regulated Learning dan Self Efficacy Terhadap Hasil Belajar Ekonomi Peserta Didik dalam Pembelajaran Daring di Era Covid-19 - A Muti'atuz Zahro, Jun Surjanti

DOI: https://doi.org/10.31004/edukatif.v3i4.560

\section{METODE PENELITIAN}

Dalam penelitian ini jenis dari pendekatan yang digunakan adalah kuantitatif. Sedangkan jenis penelitian ini menggunakan tipe asosiatif kausal yang mana memiliki tujuan guna mengetahui korelasi antara self regulated learning (X1) dan self efficacy (X2) terhadap hasil belajar ekonomi (Y). Penelitian ini untuk jumlah populasinya adalah seluruh pebelajar jurusan IPS MA Sunan Ampel yang berjumlah 128 peserta didik. Sedangkan jumlah sampel yang diperoleh adalah 92 responden. Teknik sampling yang diterapkan adalah proportional stratified random sampling dikarenakan anggota populasi yang ada terdiri dari berbagai strata (tingkatan) yakni kelas X IPS, kelas XI IPS, dan kelas XII IPS. Adapun data self regulated learning dan self efficacy peserta didik dalam penelitian ini diperoleh dari penyebaran kuesioner yang terlebih dahulu telah dilakukan serangkaian pengujian validitas maupun pengujian reliabilitas. Pengujian validitas dan reliabilitas kuesioner dilakukan terhadap 10 responden pebelajar. Penelitian ini untuk variabel self regulated learning mengadopsi kuesioner yang dikembangkan oleh Martinez-lopez \& Yot, dkk (2017) dalam jurnalnya yang berjudul "Online Self Regulated Learning Questionnaire In a Rusiian MOOC". Sedangkan untuk variabel self efficacy mengadopsi kuesioner yang dikembangkan oleh Tsai \& Cho, dkk (2020) dalam jurnalnya yang berjudul "The Self Efficacy Questionnaire for Online Learning School (SeQol)". Adapun data hasil belajar ekonomi peserta didik diperoleh dari dokumen nilai murni UAS Ekonomi semester gasal tahun ajaran 2020/2021 yang diberikan oleh guru ekonomi. Rangkaian data yang terkumpul selanjutnya dilakukan analisa dengan analisis regresi linier berganda meliputi uji prasyarat analisis yang terdiri atas uji normalitas; uji linearitas; uji multikoliniearitas; dan uji heteroskedastisitas, serta uji hipotesis yang terdiri atas uji t; uji F; dan uji R-square. Penelitian ini untuk proses analisis data dibantu dengan program SPSS.

\section{HASIL DAN PEMBAHASAN PENELITIAN}

Berdasarkan rangkaian uji validitas dan reliabilitas terhadap kuesioner yang digunakan pada penelitian ini berbantu program aplikasi SPSS, diketahui untuk kuesioner self regulated learning dari 24 item pernyataan sebanyak 22 item dinyatakan valid karena memiliki taraf signifikansi di atas 0,632 dan 2 item dinyatakan tidak valid karena memiliki taraf signifikansi di bawah 0,632. Dalam penelitian ini apabila ditemukan item pernyataan tidak valid maka langkah yang diambil item tersebut dibuang dan tidak digunakan dalam penelitian sehingga total item pernyataan kuesioner self regulated learning yang digunakan sebanyak 22 butir. Adapun untuk uji validitas kuesioner self efficacy dari 25 item pernyataan sebanyak 23 item dinyatakan valid karena memiliki taraf signifikansi di atas 0,632 dan 2 item dinyatakan tidak valid karena memiliki taraf signifikansi di bawah 0,632. Dalam penelitian ini apabila ditemukan item pernyataan tidak valid maka item tersebut dibuang dan tidak digunakan dalam penelitian sehingga total item pernyataan kuesioner self efficacy dalam penelitian ini sebanyak 23 butir. Sedangkan hasil uji reliabilitas kuesioner, diketahui untuk instrumen kuesioner self regulated learning dinyatakan reliabel dikarenakan memiliki nilai Cronbach's Alpha sebesar $0,974>0,60$. Adapun untuk instrumen kuesioner self efficacy juga dinyatakan reliabel dikarenakan memiliki nilai Cronbach's Alpha sebesar 0,975 > 0,60.

Dalam penelitian ini, dari hasil uji normalitas data diperoleh nilai Asymp. Sig. (2-tailed) sebesar 0,200 > $5 \%$ yang mana memperlihatkan jika data self regulated learning, self efficacy, dan hasil belajar terdistribusi normal. Untuk hasil uji linearitas nilai Deviation from Linearity X1 diperoleh sebesar 0,104 dan nilai Deviation from Linearity X2 diperoleh sebesar 0,101. Kedua nilai tersebut lebih besar dari 5\% sehingga diambil keputusan bahwa model regresi lolos uji linearitas. Untuk hasil uji multikolinearitas didapatkan nilai tolerance X1 dan X2 sebesar 0,115, sedangkan nilai VIF X1 dan VIF X2 sebesar 8,715. Berdasarkan hasil tersebut diketahui bahwa perolehan nilai tolerance X1 maupun X2 lebih besar dari 0,10 dan perolehan nilai VIF X1 maupun X2 kurang dari 10, sehingga diambil keputusan bahwa model regresi terbebas dari multikoliniearitas. Sedangkan untuk uji heteroskedastisitas diketahui bahwa perolehan signifikansi X1 adalah 
1474 Pengaruh Self Regulated Learning dan Self Efficacy Terhadap Hasil Belajar Ekonomi Peserta Didik dalam Pembelajaran Daring di Era Covid-19 - A Muti'atuz Zahro, Jun Surjanti

DOI: https://doi.org/10.31004/edukatif.v3i4.560

0,705 dan perolehan signifikansi X2 adalah 0,409. Kedua perolehan probabilitas signifikansi tersebut lebih besar dari 5\% sehingga diambil keputusan bahwa model regresi terbebas dari heteroskedastisitas.

\section{Tabel 1. Uji t-statistik}

Coefficients $^{\mathrm{a}}$

\begin{tabular}{|c|c|c|c|c|c|c|}
\hline \multirow{2}{*}{\multicolumn{2}{|c|}{ Model }} & \multicolumn{2}{|c|}{$\begin{array}{l}\text { Unstandardized } \\
\text { Coefficients }\end{array}$} & \multirow{2}{*}{$\begin{array}{c}\text { Standardized } \\
\text { Coefficients } \\
\text { Beta }\end{array}$} & \multirow[b]{2}{*}{$\mathrm{t}$} & \multirow[b]{2}{*}{ Sig. } \\
\hline & & $\mathrm{B}$ & Std. Error & & & \\
\hline \multirow[t]{3}{*}{1} & (Constant) & 19,864 & 3,821 & & 5,198 &, 000 \\
\hline & $\mathrm{X} 1$ & ,540 & 163 & ,496 & 3,312 & ,001 \\
\hline & $\mathrm{X} 2$ & ,302 & ,114 & 395, & 2,641 & ,010, \\
\hline
\end{tabular}

a. Dependent Variable: $\mathrm{Y}$

\section{Pengaruh Self Regulated Learning Terhadap Hasil Belajar Ekonomi Dalam Pembelajaran Daring di Era Covid-19}

Dari keterangan tabel 1 diperoleh nilai signifikansi variabel X1 (self regulated learning) sebesar 0,001 $<5 \%$. Ini menginformasikan bahwa variabel X1 (self regulated learning) secara positif dan signifikan berkorelasi terhadap variabel Y (hasil belajar ekonomi) peserta didik dalam aktivitas pembelajaran yang dilaksanakan daring di era Covid-19. Dalam aktivitas belajar yang dilaksanakan melalui daring di era Covid 19, guru tidak dapat memantau dan mengarahkan rangkaian kegiatan belajar peserta didik secara langsung. Peserta didik dituntut agar mampu mengelola dan memiliki kesadaran serta tanggung jawab dalam proses belajarnya masing-masing. Self regulated learning yang optimal sangat dibutuhkan oleh seorang pebelajar karena dapat meningkatkan hasil belajar yang didapatkan. Hasil tersebut sejalan dengan penelitian yang menyatakan bahwa self regulated learning berhubungan secara positif terhadap hasil akademik dikarenakan seseorang dengan hasil belajar tinggi lebih banyak menggunakan strategi pengaturan diri, mampu mengenali lingkungan dan kebutuhan belajar, mencari bantuan saat membutuhkan, dan memiliki keterampilan manajemen (Agustiani et al., 2016). Pendapat lain juga menyebutkan bahwa self regulated learning berkorelasi positif signifikan terhadap pencapaian akademik dikarenakan self regulated learning berkaitan dengan bagaimana peserta didik mengasosiasikan pikiran dan tindakan mereka, mengatur, merencanakan, dan mengembangkan kebutuhan belajarnya sehingga berdampak pada hasil akademik yang diperoleh (Alotaibi et al., 2017). Self regulated learning yang mumpuni dari diri seorang peserta didik memungkinkan mereka memiliki inisiatif dan kegigihan dalam belajar serta mampu memecahkan permasalahan yang dihadapi dalam proses belajar. Hasil penelitian ini turut memperkuat penelitian yang menunjukkan peserta didik di sekolah berprestasi tinggi turut memiliki self regulated learning dengan tingkatan yang juga lebih tinggi (Guo et al., 2019). Seorang pebelajar dengan self regulated learning tinggi mampu melakukan rangkaian kegiatan belajar atas dasar kehendak yang timbul dari keinginan sendiri bukan berdasarkan paksaan dari pihak lain. Self regulated learning yang tinggi membantu seorang individu pebelajar menjadi fleksibel, kreatif, termotivasi, dapat menyesuaikan dirinya ketika bekerja sama dengan yang lain, mampu melakukan analisa, berpikir serta menyesuaikan metode pemikiran mereka sendiri. Penelitian lain turut melaporkan bahwa kelompok peseta didik self regulated learning rendah memperoleh hasil belajar lebih rendah, sedangkan kelompok peserta didik self regulated learning tinggi menunjukkan hasil belajar lebih tinggi (Xiao et al., 2019); (Dörrenbächer \& Perels, 2016). Penelitian ini turut mendukung pula hasil penelitian lain di waktu sebelumnya bahwa self regulated learning secara signifikan memiliki pengaruh terhadap hasil akademik seorang pebelajar (Shing \& Rameli, 2020); (Yahaya et al., 2020). Ketika peserta didik dapat belajar atas niat yang tumbuh dalam benaknya sendiri maka ia akan mampu mengatur diri dengan baik, mampu mengelola belajarnya secara efektif, memiliki ketekunan, kemandirian dan memiliki kesadaran untuk belajar secara rutin. Seorang individu 
yang mampu mengembangkan dan mengatur dirinya dalam proses belajar akan menjadi individu pebelajar yang tanggung jawab, disiplin dalam belajar, termotivasi, dan mampu memecahkan permasalahan dalam proses belajar sehingga dapat menguasai kompetensi yang diajarkan secara optimal dan hasil belajar tercapai sesuai yang diharapkan.

\section{Pengaruh Self Efficacy Terhadap Hasil Belajar Ekonomi Dalam Pembelajaran Daring di Era Covid-19}

Dari keterangan tabel 1 juga diperoleh nilai signifikansi variabel X2 (self efficacy) sebesar $0,010<5 \%$. Ini menunjukkan bahwa terdapat korelasi positif signifikan variabel X2 (self efficacy) terhadap variabel Y (hasil belajar ekonomi) peserta didik dalam pembelajaran secara daring di era Covid-19. Selama Covid-19 aktivitas pembelajaran dilaksanakan melalui daring. Aktivitas belajar daring yang dilaksanakan di era Covid19 memicu beberapa permasalahan peserta didik seperti kekhawatiran dan ketidakpercayaan diri selama mengikuti rangkaian aktivitas pembelajaran juga kebingungan dan mudah menyerah ketika dihadapkan pembelajaran yang agak sukar. Dalam pembelajaran secara daring self efficacy diperlukan guna mendapatkan hasil belajar yang optimal sesuai target yang ditetapkan. Dengan adanya self efficacy yang optimal maka peserta didik memiliki kepercayaan bahwa ia mampu melalui rangkaian proses belajar dengan baik sehingga mempengaruhi hasil belajar. Hasil dari penelitian ini searah dengan penelitian waktu sebelumnya yang menyebutkan bahwa self efficacy berkorelasi dengan kemampuan individu pebelajar dalam mengelola kognisi dan kepercayaan diri mereka saat melakukan tes sehingga pebelajar dengan self efficacy tinggi mampu meraih skor yang lebih tinggi tinggi begitupun sebaliknya (Martin et al., 2019). Pendapat lain menyebutkan meningkatnya efikasi diri pada gilirannya turut mempengaruhi kinerja ujian menjadi lebih baik dikarenakan pebelajar dengan self efficacy yang baik mampu menetapkan tujuan lebih tinggi dan realistis, merencanakan dan memantau dengan lebih baik, dan melaporkan kecemasan lebih rendah, yang pada gilirannya mendorong keberhasilan prestasi akademik (Roick \& Ringeisen, 2017). Hasil penelitian ini memperkuat penelitian yang melaporkan bahwa self efficacy secara signifikan terdapat korelasi dengan nilai hasil belajar (Tiyuri et al., 2018); (Ayllon et al., 2019). Penelitian lain pada waktu sebelumnya menyatakan self efficacy dapat sangat mempengaruhi ekologi belajar untuk mengembangkan perilaku keberlanjutan, keberlanjutan perilaku dapat ditingkatkan dengan meningkatkan efikasi diri karena efeknya dalam memediasi keberhasilan pembelajaran ekologi partisipatif (Surjanti et al., 2020). Efikasi diri yang tertanam dalam diri seorang pebelajar dapat mempengaruhi pilihan seorang individu, tujuan yang hendak dicapai, pemecahan masalah yang dilakukan, serta kegigihan dan keuletan seorang individu pebelajar dalam berusaha. Hasil penelitian ini turut pula memperkuat hasil penelitian lain bahwa seorang individu pebelajar dengan self efficacy tingkatan lebih tinggi cenderung meraih hasil belajar lebih tinggi (Honicke \& Broadbent, 2016). Self efficacy seorang peserta didik memegang peranan penting dalam pembelajaran daring dikarenakan akan turut mendorong peserta didik dalam rangka menyelesaikan dan menghadapi tantangan yang ada guna mencapai hasil belajar yang diharapkan. Self efficacy berpengaruh secara signifikan terhadap nilai perkuliahan dan pembelajaran praktis (Lee \& Mao, 2016). Self efficacy berkorelasi positif dengan hasil belajar dikarenakan seorang pebelajar dengan tingkatan self-efficacy tinggi lebih siap untuk menghadapi berbagai tugas sulit dan menantang dan juga berusaha semaksimal mungkin mempertahankan tindakan mereka agar tercapai tujuan pembelajaran (Agustiani et al., 2016). Peserta didik dengan tingkat efikasi diri tinggi maka akan memiliki kepercayaan bahwa ia mampu melalui rangkaian proses belajar dengan baik, mampu mengerjakan setiap tugas yang dibebankan padanya, juga percaya diri bahwa mampu mencapai hasil belajar optimal sesuai target yang ditentukan. 
Tabel 2. Uji F

ANOVA $^{\mathrm{a}}$

\begin{tabular}{|ll|c|r|r|r|r|}
\hline \multicolumn{2}{|l|}{ Model } & $\begin{array}{c}\text { Sum of } \\
\text { Squares }\end{array}$ & df & Mean Square & F & Sig. \\
\hline 1 & Regression & 7427,650 & 2 & 3713,825 & 149,924 &, $000^{\mathrm{b}}$ \\
& Residual & 2204,654 & 89 & 24,771 & & \\
& Total & 9632,304 & 91 & & & \\
\hline
\end{tabular}

a. Dependent Variable: Y

b. Predictors: (Constant), X2, X1

\section{Pengaruh Self Regulated Learning dan Self Efficacy Terhadap Hasil Belajar Ekonomi Dalam Pembelajaran Daring di Era Covid-19}

Berdasarkan keterangan tabel 2 nilai signifikansi diperoleh sebesar $0,000<5 \%$. Ini memberitahukan bahwa secara bersama-sama terdapat pengaruh self regulated learning dan self efficacy terhadap hasil belajar ekonomi peserta didik jurusan IPS MA Sunan Ampel dalam aktivitas belajar yang dilaksanakan secara daring di era Covid-19. Sebagaimana yang dikemukakan penelitian sebelumnya bahwa self regulated learning dan self efficacy sangat berpengaruh terhadap pencapaian belajar peserta didik yang dibuktikan dengan korelasi positif antara ketiga variabel tersebut (Agustiani et al., 2016). Ketika seorang pebelajar dalam dirinya terdapat self regulated learning yang optimal maka akan belajar atas niat yang tumbuh dalam benaknya sendiri, mampu mengatur diri dengan baik, mampu mengelola belajarnya secara efektif, memiliki ketekunan, kemandirian dan memiliki kesadaran untuk belajar secara rutin sehingga berdampak pada hasil belajar. Hasil dari penelitian ini turut pula diperkuat dengan penelitian pada waktu sebelumnya yang menyatakan bahwa kelompok pelajar dengan self regulated learning tinggi turut pula memperoleh hasil belajar dengan capaian lebih tinggi, begitupun sebaliknya kelompok pelajar dengan self regulated learning turut menunjukkan hasil belajar yang lebih rendah (Guo et al., 2019); (Xiao et al., 2019); dan (Dörrenbächer \& Perels, 2016). Hasil penelitian lain juga menyatakan bahwa self regulated learning secara signifikan memiliki korelasi terhadap pencapaian hasil akademis peserta didik (Alotaibi et al., 2017); (Shing \& Rameli, 2020); dan (Yahaya et al., 2020). Sedangkan peran penting self efficcacy terhadap capaian hasil belajar peserta didik turut ditunjukkan dalam penelitian sebelumnya yang menyebutkan bahwa seorang pebelajar dengan tingkat self efficacy lebih tinggi cenderung meraih hasil belajar yang lebih baik (Martin et al., 2019); (Roick \& Ringeisen, 2017); dan (Honicke \& Broadbent, 2016). Peran penting dari self efficcacy dalam pembelajaran juga terdapat dalam penelitian yang menyatakan bahwa self efficacy dapat sangat mempengaruhi ekologi belajar untuk mengembangkan perilaku keberlanjutan, keberlanjutan perilaku dapat ditingkatkan dengan meningkatkan efikasi diri karena efeknya dalam memediasi keberhasilan pembelajaran ekologi partisipatif (Surjanti et al., 2020). Self efficacy memainkan peranan penting dikarenakan akan turut memotivasi peserta didik dalam rangka menyelesaikan dan menghadapi tantangan guna mendapatkan hasil belajar yang ditargetkan. Hasil dari penelitian lain juga melaporkan bahwa secara positif juga signifikan terdapat pengaruh antara self efficacy dengan hasil belajar (Ayllon et al., 2019); (Tiyuri et al., 2018). Sementara penelitian yang dilakukan Lee \& Mao (2016) melaporkan self efficacy berpengaruh secara signifikan terhadap nilai perkuliahan dan pembelajaran praktis. Self regulated learning berkaitan dengan kemampuan seorang individu untuk mengembangkan dan juga mengatur dirinya dalam proses yang berlangsung selama aktivitas belajar sehingga menjadi pebelajar yang tanggung jawab, disiplin dalam belajar, termotivasi, dan mampu memecahkan permasalahan yang dihadapi sehingga dapat menguasai kompetensi yang diajarkan. Sedangkan self efficacy berkaitan dengan keyakinan dan kepercayaan diri yang tertanam dalam individu peserta didik terkait kemampuan yang dimilikinya untuk melaksanakan rangkaian kegiatan belajar maupun menyelesaikan berbagai tugas yang diberikan sehingga dapat mencapai target belajar yang diharapkan. Dengan adanya self 
1477 Pengaruh Self Regulated Learning dan Self Efficacy Terhadap Hasil Belajar Ekonomi Peserta Didik dalam Pembelajaran Daring di Era Covid-19 - A Muti'atuz Zahro, Jun Surjanti

DOI: https://doi.org/10.31004/edukatif.v3i4.560

regulated learning dan self efficacy yang optimal maka akan mendorong peningkatan hasil belajar peserta didik.

Tabel 3. Uji R-square

Model Summary

\begin{tabular}{|l|r|r|r|r|}
\hline Model & R & R Square & Adjusted R Square & \multicolumn{1}{|c|}{$\begin{array}{c}\text { Std. Error of the } \\
\text { Estimate }\end{array}$} \\
\hline 1 &, $878^{\mathrm{a}}$ &, 771 &, 766 & 4,97709 \\
\hline
\end{tabular}

a. Predictors: (Constant), X2, X1

Adapun berdasarkan keterangan tabel 3 diperoleh nilai koefisien determinasi R-Square sebesar 0,771. Hasil tersebut melaporkan bahwa sebesar $77,1 \%$ variabel Y (hasil belajar) dipengaruhi oleh variabel X1 (self regulated learning) dan X2 (self efficacy), adapun sisanya sebesar 22,9\% dipengaruhi oleh variabel lain yang tidak diikutsertakan dalam model. Ini memperlihatkan bahwa secara bersama-sama self regulated learning dan self efficacy berpengaruh kuat terhadap hasil belajar ekonomi peserta didik jurusan IPS MA Sunan Ampel dalam aktivitas belajar yang dilaksanakan secara daring di era penyebaran Covid-19. Hasil tersebut sesuai dengan penelitian waktu terdahulu yang mengungkapkan bahwa individu pebelajar self regulated learning optimal meraih hasil belajar tinggi karena lebih banyak menggunakan strategi pengaturan diri, mampu mengenali lingkungan dan kebutuhan belajar, mencari bantuan saat membutuhkan, dan memiliki keterampilan manajemen, sedangkan individu pebelajar dengan self efficacy yang baik lebih siap untuk menghadapi berbagai tugas sulit dan menantang dan juga berusaha semaksimal mungkin mempertahankan tindakan mereka agar tercapai tujuan pembelajaran (Agustiani et al., 2016). Mengingat peran penting kedua variabel tersebut dalam pencapaian hasil belajar, maka baik self regulated learning dan juga self efficacy perlu di tingkatkan dalam rangka mencapai hasil belajar yang optimal. Guru dapat meningkatkan self regulated learning dengan cara mengenalkan peserta didik dengan kebutuhan belajarnya seperti apa saja materi yang perlu dipelajari serta alasan mengapa materi tersebut penting untuk dipelajari sehingga menumbuhkan inisiatif dan kesadaran dalam belajar. Peserta didik juga didorong untuk menetapkan target belajarnya sekaligus memanajemen jadwal belajar secara cermat sehingga kegiatan belajar menjadi terarah. Adapun upaya guru untuk meningkatkan self efficacy peserta didik dapat dilakukan dengan menunjukkan bagaimana peserta didik mengindetifikasi kegiatan belajar yang perlu dilakukan, menentukan tugas mana yang harus terlebih dahulu diprioritaskan, dan peserta didik didorong untuk mengevaluasi hasil belajarnya sendiri secara konsisten. Guru juga dapat menunjukkan contoh-contoh keberhasilan yang telah dicapai peserta didik, karena dengan mengamati keberhasilan-keberhasilan tersebut akan membentuk opini peserta didik mengenai kemampuannya sendiri dan menumbuhkan keyakinan serta kepercayaan diri dalam belajar. Dengan dilakukannya penelitian ini, maka diharapkan dapat menjadi sumber informasi bagi pihak sekolah terkait peranan penting self regulated learning dan self efficacy terhadap hasil belajar sehingga dapat membantu upaya peningkatan hasil belajar dalam aktivitas pembelajaran yang dilaksanakan melalui daring terutama di era Covid-19. Keterbatasan penelitian ini yakni hanya dilakukan terbatas pada lingkup pebelajar di jurusan IPS MA Sunan Ampel sehingga untuk mengetahui bagaimana peranan self regulated learning dan self efficacy terhadap hasil belajar selama pembelajaran daring di era pandemi dalam lingkup yang lebih luas, maka diperlukan penelitian lebih lanjut. Bagi peneliti selanjutnya diharapkan dapat lebih menggali serta menngeksplorasi terkait peranan penting self regulated learning maupun self efficacy dalam aktivitas belajar mengajar daring yang dilaksanakan sekolah lain sehingga dapat dijadikan pembandiing dengan hasil penelitian ini.

\section{KESIMPULAN}

Berdasarkan pemaparan hasil penelitian dan pembahasan yang tercantum di atas, maka dalam penelitian ini diperoleh kesimpulan bahwa secara positif dan signifikan self regulated learning berpengaruh terhadap 
1478 Pengaruh Self Regulated Learning dan Self Efficacy Terhadap Hasil Belajar Ekonomi Peserta Didik dalam Pembelajaran Daring di Era Covid-19 - A Muti'atuz Zahro, Jun Surjanti

DOI: https://doi.org/10.31004/edukatif.v3i4.560

hasil belajar ekonomi peserta didik dalam aktivitas belajar yang dilaksanakan secara daring di era Covid-19. Variabel self efficacy secara positif dan signifikan juga memiliki pengaruh terhadap hasil belajar ekonomi peserta didik dalam pembelajaran secara daring di era Covid-19. Hasil penelitian dari variabel ini turut melaporkan bahwa self regulated learning dan self efficacy secara bersama-sama berpengaruh kuat terhadap hasil belajar ekonomi peserta didik dalam dalam aktivitas belajar yang dilaksanakan secara daring di era Covid-19. Semakin tinggi tingkat self regulated learning dan self efficacy seorang pebelajar maka semakin optimal hasil belajar yang dicapai. Mengingat peran penting kedua variabel tersebut dalam pencapaian hasil belajar maka baik self regulated learning dan juga self efficacy perlu di tingkatkan dalam rangka mencapai hasil belajar yang optimal.

\section{UCAPAN TERIMA KASIH}

Peneliti mengucapkan terima kasih kepada pihak MA Sunan Ampel sebagai sekolah mitra yang telah mengijinkan peneliti untuk melaksanakan penelitian terhadap seluruh peserta didik jurusan IPS MA Sunan Ampel yang terdiri atas kelas X IPS, XI IPS, dan XII IPS pada aktivitas belajar secara daring di era Covid-19 semester gasal tahun ajaran 2020/2021.

\section{DAFTAR PUSTAKA}

Abisha Meji, M., \& Dennison, M. S. (2020). Survey on General Awareness, Mental State and Academic Difficulties Among Students Due to COVID-19 Outbreak in the Western Regions of Uganda. Heliyon, 6(11). https://doi.org/10.1016/j.heliyon.2020.e05454

Achufusi, N. ., Utakaj.N, .C, O. C., \& Okonkwoe.O. (2019). Secondary School Student's Self Efficacy and Motivation as Correlates of Their Achievement in Physics. Journal of Research \& Method in Education, 9(3), 75-80. https://doi.org/10.9790/1959-0903017580

Agustiani, H., Cahyad, S., \& Musa, M. (2016). Self-efficacy and Self Regulated Learning as Predictors of Student's Academic Performance. The Open Psychology Journal, 9(1), 1-6. https://doi.org/10.2174/1874350101609010001

Alotaibi, K., Tohmaz, R., \& Jabak, O. (2017). The Relationship Between Self Regulated Learning and Academic Achievement for a Sample of Community College Students at King Saud University. International Education Journal, 6(1), 28-37. https://doi.org/10.11648/j.edu.20170601.14

Argaheni, N. B. (2020). Sistematik Review: Dampak Perkuliahan Daring Saat Pandemi COVID-19 Terhadap Mahasiswa Indonesia. PLACENTUM: Jurnal Ilmiah Kesehatan Dan Aplikasinya, 8(2), 99-108. https://doi.org/10.20961/placentum.v8i2.43008

Ayllon, S., Alsina, A., \& Colomer, J. (2019). Teacher's involvement and student's self efficacy: Keys to achievement in higher education. International Journal of Educational Research, 1-11. https://doi.org/10.5061/dryad.Introduction

Dörrenbächer, L., \& Perels, F. (2016). Self-regulated learning profiles in college students : Their relationship to achievement, personality, and the effectiveness of an intervention to foster self regulated learning. Learning and Individual Differences, 51, 229-241. https://doi.org/10.1016/j.lindif.2016.09.015

Guo, W., Lau, K. L., \& Wei, J. (2019). Teacher feedback and student's self regulated learning in mathematics: A comparison between a high achieving and a low achieving secondary schools. Studies in Educational Evaluation, 63, 48-58. https://doi.org/10.1016/j.stueduc.2019.07.001

Honicke, T., \& Broadbent, J. (2016). The influence of academic self efficacy on academic performance : A systematic review. Educational Research Review, 17, 63-84 https://doi.org/10.1016/j.edurev.2015.11.002 
1479 Pengaruh Self Regulated Learning dan Self Efficacy Terhadap Hasil Belajar Ekonomi Peserta Didik dalam Pembelajaran Daring di Era Covid-19 - A Muti'atuz Zahro, Jun Surjanti

DOI: https://doi.org/10.31004/edukatif.v3i4.560

Lee, P. C., \& Mao, Z. (2016). The relation among self efficacy, learning approaches, and academic performance: an exploratory study. Journal of Teaching in Travel \& Tourism, 2-18. https://doi.org/10.1080/15313220.2015.1136581

Liputan 6. (2020). SMRC: 92 Persen Siswa Merasa Pembelajaran Daring Banyak Masalah. https://www.liputan6.com/news/read/4333838/smrc-92-persen-siswa-merasa-pembelajaran-daringbanyak-masalah

Martin, A. J., Malmberg, L. E., Kennett, R., Mansour, M., Papworth, B., \& Pearson, J. (2019). What happens when students reflect on their self efficacy during a test? Exploring test experience and test outcome in science. Learning and Individual Differences, 73, 59-66. https://doi.org/10.1016/j.lindif.2019.05.005

Martinez-lopez, R., Yot, C., \& Tuovila, I. (2017). Online Self Regulated Learning Questionnaire in a Russian MOOC. Computers in Human Behavior. https://doi.org/10.1016/j.chb.2017.06.015

Patricia, A. (2020). College Student's Use and Acceptance of Emergency Online Learning Due to COVID-19. International Journal of Educational Research Open, 100-108. https://doi.org/10.1016/j.ijedro.2020.100011

Roick, J., \& Ringeisen, T. (2017). Self efficacy, test anxiety, and academic success : A longitudinal validation. International Journal of Educational Research, 83, 84-93. https://doi.org/10.1016/j.ijer.2016.12.006

Saraswati, P. (2017). Self Regulated Learning Strategy, academic procrastionation and academic achievement. Jurnal Psikologi Ilmiah, 9(3), 210-223. https://doi.org/10.15294/intuisi.v9i3.14112

Shing, L. S., \& Rameli, M. R. M. (2020). The influence of self regulation towards academic achievement in English among Malaysian upper primary students. Universal Journal of Educational Research, 8, 1-11. https://doi.org/10.13189/ujer.2020.081901

Sintema, E. J. (2020). Effect of COVID-19 on the performance of grade 12 students: Implications for STEM education. Eurasia Journal of Mathematics, Science and Technology Education, 16(7), 1-6. https://doi.org/10.29333/EJMSTE/7893

Surjanti, J., Soejoto, A., \& Nugroho, D. (2020). Social Sciences \& Humanities Open Mangrove forest ecotourism: Participatory ecological learning and sustainability of student's behavior through self efficacy and self concept. Social Sciences \& Humanities Open, 2(1). https://doi.org/10.1016/j.ssaho.2019.100009

Tiyuri, A., Saberi, B., Miri, M., Shahrestanaki, E., Bayat, B. B., \& Salehiniya, H. (2018). relationship with academic performance in postgraduate students of Tehran University of Medical Sciences in 2016. Journal of Education and Health Promotion, 3-8. https://doi.org/10.4103/jehp.jehp

Tsai, C., Cho, M., Marra, R., Shen, D., \& Marra, R. (2020). The Self-Efficacy Questionnaire for Online Learning (SeQoL ). Distance Education, OO(00), 1-18. https://doi.org/10.1080/01587919.2020.1821604

Xiao, S., Yao, K., \& Wang, T. (2019). The Relationships of Self Regulated Learning and Academic Achievement in University Students. International Journal of Educational Research, 4-7. https://doi.org/https://doi.org/10.1051/shsconf/2019 6001003

Yahaya, A., Maakip, I., Voo, P., Yunus, M., \& Yusuf, M. (2020). Effects of Self Regulated Learning , Parental Involvement and Homework on Academic Achievement of School Students. International Journal of Academic Research in Progressive Education and Development, 9(2), 380-397. https://doi.org/10.6007/IJARPED/v9-i2/7419 